\title{
“THE SUPPRESSED BOOK!": A PREVIOUSLY UNREPORTED WHITMAN BROADSIDE
}

Reprinted on the back cover of this issue is a previously unreported broadside for Leaves of Grass, now in the Kendall Reed Collection and reproduced with Dr. Reed's permission. On the verso of this advertisement, which offers Whitman's "suppressed book!" in a reprint of the banned 1881 Boston Osgood edition, is an offer for "Cabinet Photographs" of well-known writers and other celebrities. The sales agent is one E. C. Walker, of Norway, Iowa. This broadside is particularly suggestive in that it proffers Leaves as a book that-precisely because it has been judged "'obscene' by the authorities of Massachusetts"-should now be "bought and read by every truth- and liberty-loving man and woman, both for its intrinsic merits and to vindicate the right to Publish, now menaced by the ignorant and prurient minions of an effete and intolerant Church, and tyrannous, invasive State." Directly below the ad-copy for Leaves is an announcement of "The Apochryphal New Testament," "just the book to enlighten your Christian neighbor."

Little is known of E. C. Walker, ${ }^{2}$ and the date of the broadside is uncertain, though the reference to the Osgood plates and to the Boston controversy suggests a date right around 1882 (the subjects of the photographs for sale on the verso also support an early 1880 s date). Walker was probably distributing copies of Philadelphia publisher Rees Welsh's reprint of the Osgood edition; Rees Welsh and Company took over the publication after James R. Osgood withdrew his edition and sold the plates to Whitman when Boston district attorney Oliver Stevens ruled that Leaves was obscene literature and demanded the removal of certain poems and passages. If nothing else, the broadside demonstrates that not all early Iowans shared the view of Secretary of Interior James Harlan (of Mount Pleasant, Iowa) that Leaves was an "indecent" book. Walker, on the contrary, sounds very much like William Douglas O'Connor, who of course defended Leaves and its author against Harlan in 1865 and against the Boston suppression in 1882, in both cases railing against the prudery and tyranny of state forces. ${ }^{3}$

O'Connor originally published "Suppressing Walt Whitman," his blistering attack on the Boston district attorney and on Osgood and Company, in the New York Tribune on May 25, 1882. O'Connor's piece was reprinted in Truth Seeker - self-described as "a magazine for free thinkers"4 - on June 10, 1882. Over the next few months, a lively debate about Whitman's work appeared in this journal, and in the November 25 issue, E. C. Walker contributed "Words in Brief," a spirited defense of Whitman's poems, which, he claimed, were indecent only to those with vile minds. ${ }^{4}$ The similarities between Walker's broadside and his Truth Seeker article suggest that the broadside was issued in the heat of the Boston controversy. 


\section{NOTES}

1 The Apocryphal New Testament, in an English translation originally published in 1820 by William Hone in London, England, was reprinted in a number of editions in the United States during the 1800s.

2 "Ed. C. Walker" is listed among the noted residents of Florence Township (where Norway is located) in The History of Benton County, Iowa (Chicago: Western Historical Company, 1878), 629.

3 See Jerome Loving, Walt Whitman's Champion (College Station: Texas A\&M University Press, 1978), which reprints O'Connor's 1865 “The Good Gray Poet: A Vindication" (157-203) and his 1882 "Suppressing Walt Whitman" (217-225).

4 Truth Seeker began as a tabloid newspaper, founded in 1873 by D. M. Bennett (1818-1882) and his wife Mary, who devoted the journal to "science, morals, free thought, free discussions, liberalism, sexual equality, labor reform, progression, free education and whatever tends to elevate and emancipate the human race." The journal was opposed to "priestcraft, ecclesiasticism, dogmas, creeds, false theology, superstition, bigotry, ignorance, monopolies, aristocracies, privileged classes, tyranny, oppression, and everything that degrades or burdens mankind mentally or physically." Thomas Edison, Clarence Darrow, Mark Twain, Robert G. Ingersoll, H. L. Mencken, Elizabeth Cady Stanton, Margaret Sanger, and Horace Traubel all published in the journal or otherwise supported it. Truth Seeker is still in existence, and information about the journal is available online at www.truthseeker.com.

5 Truth Seeker 9 (November 25, 1882), 746-747. For summaries of all the Truth Seeker articles on Whitman during this year, see Scott Giantvalley, Walt Whitman, 1838-1939: A Reference Guide (Boston: G. K. Hall, 1981), 57-66. 